\title{
Reading Preferences and Strategies Employed by Primary School Students: Gender, Socio-Cognitive and Citizenship Issues
}

\author{
Eleni Griva (Corresponding author) \\ Assistant Professor, School of Education, University of Western Macedonia \\ 3rd km Florina - Niki, 53100 Florina, Greece \\ Tel: 3-023-8505-5027_Ｅ-mail: egriva@otenet.gr \\ Anastasia Alevriadou \\ Associate Professor, School of Education, University of Western Macedonia \\ 3rd km Florina - Niki, 53100 Florina, Greece \\ Tel: 3-023-8505-5085_ E-mail: alevriadou@uowm.gr
}

Klio Semoglou

Lecturer, School of Education, University of Western Macedonia

3rd km Florina - Niki, 53100 Florina, Greece

Tel: 3-023-8505-5050_E-mail: ksemoglou@uowm.gr

Received: September 10, 2011 Accepted: October 19, 2011 Published: April 1, 2012

doi:10.5539/ies.v5n2p24

URL: http://dx.doi.org/10.5539/ies.v5n2p24

\begin{abstract}
The purpose of the present study was to identify the correlation between gender and reading preferences and reading strategies employed by 5th and 6th Grade students of primary school in Greece. The main objectives of the present study were (1) to identify possible differences between male and female students in employing cognitive and metacognitive strategies, (2) to record the difficulties encountered by males and females when reading and (3) to highlight possible differences between male and female students in reading preferences. 405 Greek students (206 boys and 199 girls, $\mathrm{M=11.21}$ years old, SD.=0.47) participated in the study and were asked to fill in a questionnaire including questions related to reading preferences and attitudes. In addition, 32 students from the total sample were asked to choose their favourite text to read and think aloud about the processes they followed and the strategies they used. The questionnaire results indicated significant differences between male and female students in reading preferences, since the female students showed a greater preference for 'human-interest' stories and male ones preferred to read comics and action-stories. The verbal data revealed the female students' flexibility in strategy use and their higher metacognitive awareness compared to male students. Reading, gender and social factors are discussed in the light of citizenship education.
\end{abstract}

Keywords: Reading preferences, Gender, Strategies, Citizenship, Education

\section{Introduction}

Citizenship education has been considered as a multidimensional and complex a context (Bauer, 2002), where the focus is on improving interpersonal and intercultural relationships and understanding each individuals' perspectives, preferences and responsibilities, as well as abolishing any gender bias and stereotypes (Galston, 2001; Santora, 2006). Gender stereotypes include information about physical appearance, attitudes and interests, social relations and occupations. As Witt (1997) points out, it is difficult for a child to grow to adulthood without experiencing some form of gender bias or stereotyping (Koutselini \& Agathangelou, 2008). The values assigned to the male - female citizen are reproduced in school policies and practices in a variety of ways.

One of the most important goals of education is the preparation of both male and female students for their role as active citizens. This can be achieved through using approaches appropriate for (1) developing social responsibility, that is learning socially responsible behaviour in the classroom and (2) developing both genders' literacy skills and 
communication. It has been showed that successful promotion of reading takes place mainly at school (Van Peer, 1991; Kraaykamp, 2001) and school-based reading activities promote students' identity as a 'reader', as well as their attitudes towards reading (Turner \& Paris, 1995; McCarthy \& Moje, 2002).

Reading is a sociocultural process, which is based on students' prior knowledge and it helps broadening students' experiences and knowledge developing a cultural identity and a personal sense of citizenship (Green, 2002). The family background and school context can influence students' preferences and contribute to shaping their reading attitudes and preferences (Myoungsoon \& Heekyoung, 2002). Students' attitudes to reading can be influenced by their experiences, which can change over the primary school years and may be different between female and male students. Children bring their family and cultural values, experiences and beliefs as they begin schooling (Thomson, 2002; Comber, 2004). The importance of parent/family involvement has been highlighted as a basic factor that can help children improve reading by providing motivating and pleasurable experiences with books and literacy (Ellen, 1994). Research data have shown that parental involvement with reading activities at home has significant positive influences on students' interest in reading, and their attitudes towards reading classroom (Rowe, 1991); particularly, mothers become systematically responsible for the literary socialization of their children.

Students read to locate, select, and make use of relevant information from a variety of sources and recognize them as a record of human experience. Reading from a wide variety of texts provides students with information from diverse forms and perspectives. A lot of researchers have investigated and indicated differences between male and female students in reading preferences, reading performance and strategy use (e.g., Biigel \& Buunk, 1996; Chavez, 2001). In addition, a number of studies have revealed gender differences in the amount of time devoted to reading (Gibbons, Lynn \& Stiles, 1997). It has also been found that a higher percentage of girls indulge in leisure reading than boys (Abilock, 2002; Swalander \& Taube, 2007). The female students show a more positive attitude to reading (see Swalander \& Taube, 2007) and a preference for reading a variety of genres compared to male ones (Clark, Osborne \& Akerman, 2008).

Concerning the text genres, it has been revealed that boys prefer adventure, science fiction and sports stories, while girls enjoy animal stories and stories about teenage problems (Simpson, 1998), as well as romance, friendship, animal stories and historical fiction. Shelly (1999) found that the $6^{\text {th }}$ to $8^{\text {th }}$ grade children have stronger preference for humour and horror stories, followed by mysteries, historical fiction, adventure and science fiction. Also, in Abilock's study (2002) it was revealed that the girls preferred to read books about both males and females, while the boys would choose fiction about males.

A great number of studies have focused on the cognitive aspects of reading (see for example Adams, 1990) and have stressed the need to consider the balance between cognitive and social aspects of reading and literacy (Guthrie \& Wigfield, 2000). Moreover, the effect of gender on language strategy use has been thoroughly investigated (Green \& Oxford, 1995; Chandler, Lizotte \& Rowe, 1998; Griva \& Alevriadou, 2009; Griva et al, 2009). Reading strategies (O’Malley \& Chamot, 1990) have been classified into (1) cognitive, which involve direct interaction with the text and application of specific techniques that facilitate comprehension (Davis \& Bistodeau, 1993) and (2) metacognitive strategies, which include knowledge of cognition and regulation of cognition (Carrel, 2005), help students monitor or regulate cognitive strategies (Oxford, 1990; Devine, 1993),.

A lot of studies (Oxford \& Nyikos 1989; Chavez, 2001) found a wide range of gender differences in the frequency and flexibility of strategy use. Specifically, female students employ a variety of reading strategies in coming to terms with the text and 'dealing' with the comprehension of the messages of the text (Oxford \& Nyikos, 1989; Pressley \& Afflerbach, 1995; Singhal, 2001). On the other hand, in Lee’s study (1994) it was revealed that girls showed more frequent use of cognitive, metacognitive and social strategies than boys in middle school, but not in high school and college.

Schools are to become an authentic environment, which makes room for students' preferences, interests, and developing their literacy skills. In such a context, the implications for reading instruction include the need to provide opportunities for every student to express their preferences and strategies, to encourage students' involvement in reading a variety of genres and to engage them in confronting differing perspectives.

In line with the abovementioned aspects, the present study aimed to investigate primary school students' reading preferences and interests, as well as the strategies they employ when reading. More precisely, it aimed at: (1) highlighting possible differences between male and female students in reading preferences; (2) identifying possible differences between male and female students in employing cognitive and metacognitive strategies; (3) recording the difficulties encountered by males and females when reading; (4) examining the possible influence of parents' education and occupation on students' reading behavior. 


\section{The Study}

\subsection{Sample}

The sample consisted of a total of 405 fifth and sixth grade students (206 male students and 199 female students), aged between 10 and $12(\mathrm{M}=11.2$ years-old, $\mathrm{SD}=0.45$ ). Concerning their parents' education profile, the majority of fathers and mothers have a degree in higher education (table 1). As regards their parents' occupation, most of their mothers have a profession that can be regarded as a "low autonomy profession" (see Tables 1 \&2).

\subsection{Methodology}

The study was conducted through two basic phases:

In the first phase, a self-report questionnaire was administered to 405 students to fill. The questionnaire comprised three basic sections: (1) attitudes towards leisure reading; (2) preferences for text genres; (3) difficulties encountered while reading schoolbooks. It included 'Likert-type' questions: the students were asked to indicate their preferences with 16 attitudinal statements on a scale ranging from 1 (very much) to 4 (little).

The second phase of the study was conducted by using "think aloud" process and retrospective interviews as the basic instruments. 32 students (16 girls and 16 boys) were selected to participate in this phase. They were selected according to (a) their positive attitudes to reading indicated through their responses to the questionnaire (b) their performance in a reading text and (c) classroom teachers' records. Each student was exposed to five texts (of about 300 words): one gender-neutral text, two texts with a 'male' topic and two texts with a 'female' topic: (1) nutrition, (2) football, (3) electronics, (4) ballet, and (5) fashion.

The participants were asked to report on their thoughts while they were completing the reading task (Garner, 1987); they had to think aloud all the techniques and procedures they used, as well as the difficulties they encountered. Retrospective interviews were conducted with each of the students, after terminating their reading; they were asked to comment on their strategic processes retrospectively and to assess their performance in the reading tasks (Morrison, 1996).

\subsection{Data Analysis}

Data derived from the questionnaire were analyzed by using descriptive statistical methods. Frequencies and percentages for all items of the questionnaires were obtained. Moreover, the techniques of chi-square-test $\left(\mathrm{x}^{2}\right)$ (Ind. Cramer's V), t-test, ANOVA were performed.

The verbal data underwent both qualitative and quantitative analysis: Data reduction resulted in groups of categories/sub-categories (table 7). In addition, frequencies and percentages for all categories/sub-categories were obtained. The techniques of chi-square-test $\left(\mathrm{x}^{2}\right)$ and t-test were performed in order to identify differences in strategy use between male and female students.

\section{Results}

\subsection{Questionnaire Results}

\subsubsection{Out of School Reading Preferences}

Regarding out of school reading, it was recorded that a higher percentage of female students indulge in leisure reading than male ones $\left(\mathrm{x}^{2}=75.022, \mathrm{df}=3, \mathrm{p}<.000\right)$. Also, a greater number of girls stated that they spend money on buying books $\left(x^{2}=31.065, d f=3, p<.000\right)$ and go to the lending library compared to boys $\left(x^{2}=28.337, d f=3, p<.000\right)$. On the other hand, it was the boys who gave higher percentages in terms of preferring 'watching TV' to reading books $\left(x^{2}=24,184, d f=3, p<.000\right)$ and 'playing computer games' to reading books $\left(x^{2}=30.554, d f=3, p<.000\right)($ table $3)$.

It is noteworthy that the interaction between mothers' occupation $\left(x^{2}=21.667, \mathrm{df}=3, \mathrm{p}<.000\right)$, mother's education $\left(x^{2}=26.944, d f=3, p<.000\right)$ and children's leisure reading was significant, since the children whose mothers have a "high autonomy profession" and a university degree showed a higher preference for leisure reading. Moreover, fathers' education background $\left(x^{2}=12.739, \mathrm{df}=3, \mathrm{p}<.005\right)$ as well as fathers' occupation $\left(\mathrm{x}^{2}=33.584, \mathrm{df}=3, \mathrm{p}<.001\right)$ proved to be significant factors: the higher the parents' education and occupation, the greater the children's reading preference.

In relation to going to the lending library, their mothers' occupational background $\left(\mathrm{x}^{2}=30.898 \mathrm{df}=3, \mathrm{p}<.000\right)$ and their fathers' occupational background $\left(\mathrm{x}^{2}=9.111 \mathrm{df}=3, \mathrm{p}<.05\right)$ proved to be significant: the higher the parents' education and occupation, the more positive was the children's attitudes to buying books.

Besides, the students' attitudes to buying books were influenced by their mothers' occupational $\left(\mathrm{x}^{2}=17.184 \mathrm{df}=3\right.$, $\mathrm{p}<.01)$ and educational $\left(\mathrm{x}^{2}=9.201, \mathrm{df}=3, \mathrm{p}<.05\right)$ background. Also, their fathers' educational background $\left(\mathrm{x}^{2}=12.461\right.$ 
$\mathrm{df}=3, \mathrm{p}<.01$ ) proved to be significant: the higher the parents' education and occupation, the more positive were the children's attitudes to buying books.

\subsubsection{Preferred Types of Reading Texts}

In the effort made to specify the students' preferred types of texts, it was revealed that the top three choices related to reading texts for both male and female students were the following: books with humorous stories $(\mathrm{n}=305)$, adventure books ( $n=248)$ and comics $(n=196)$ (table 4). Statistically significant differences were revealed between male and female in relation to fairy tales $\left(\mathrm{x}^{2}=32.517 \mathrm{df}=3, \mathrm{p}<.000\right)$, comics $\left(\mathrm{x}^{2}=22.127 \mathrm{df}=3, \mathrm{p}<.000\right)$, sport magazines $\left(\mathrm{x}^{2}=106.653 \mathrm{df}=3, \mathrm{p}<.000\right)$, magazines (TV/music) $\left(\mathrm{x}^{2}=51.220 \mathrm{df}=3, \mathrm{p}<.000\right)$ and poems $\left(\mathrm{x}^{2}=42.097\right.$, $\mathrm{df}=3, \mathrm{p}<.000$ ).

More precisely, sport magazines were ranked higher by male $(n=106)$ than female students. In addition, male students showed a marked preference for comics $(n=119)$ compared to female ones $(n=77)$. On the other hand, female students showed a greater interest in magazines (TV/music) $(n=66)$ and poems $(n=42)$ (table 4). Furthermore, statistically significant differences resulted from mothers' occupational background in relation to students' preferences for reading 'poems' $\left(\mathrm{x}^{2}=20.701, \mathrm{df}=3, \mathrm{p}<.000\right)$ and 'comics' $\left(\mathrm{x}^{2}=12.818 \mathrm{df}=3, \mathrm{p}<.046\right)$ (table 4).

\subsubsection{Difficulties}

With reference to the difficulties the students encountered while reading, it was declared that they face great difficulty in extensive reading, skimming the text for gist and learning a text by heart and understanding complex sentences/paragraphs (table 5). The frequency distribution of the data showed that the most difficult sub-skills were considered to be the following:

Most of the students rated 'learning a text by heart' highly in difficulty (64 boys and 73 girls), as they felt very anxious whenever they read a text and encountered comprehension problems. In addition, 'skimming the text for gist' was of high difficulty for a certain number of male $(n=42)$ and female students $(n=59)$. Complex/long sentences were declared to cause some problems to students to comprehend a text sufficiently. Significant differences were found between the two groups $\left(\mathrm{x}^{2}=12.014, \mathrm{df}=3, \mathrm{p}<.000\right)$, since it was ranked higher by the female students. Besides, 'extensive reading' constitutes a major difficulty for the girls than the male students $\left(x^{2}=9.880, d f=3, p<.05\right)$.

As regards the difficulties students encountered with complex/long sentences and paragraphs in reading texts, their mothers' occupational background $\left(\mathrm{x}^{2}=20.271, \mathrm{df}=3, \mathrm{p}<.005\right)$ as well as their fathers' occupational background $\left(\mathrm{x}^{2}=44.323, \mathrm{df}=3, \mathrm{p}<.000\right)$ proved to be significant: the lower the parents' education profile and occupational background, the more difficulties the children encountered. In addition, mothers' occupational $\left(x^{2}=14.867, d f=3\right.$, $\mathrm{p}<.05)$ and fathers' occupational $\left(\mathrm{x}^{2}=22.627, \mathrm{df}=3, \mathrm{p}<.005\right)$ background proved to be significant in relation to the difficulties children encountered in skimming the text for gist for comprehension purposes.

\subsection{Results of 'Think Aloud' Process}

\subsubsection{Preferred Reading Topics}

Regarding students' preference for selecting two texts from a total of five texts to read and think aloud, the main effect of gender and topic of reading text (nutrition, football, electronics, ballet and fashion) was analyzed by using non-parametric test chi-square. Statistical significant differences were indicated in relation to genre selection $\left(x^{2}=19,143 . \mathrm{df}=4, \mathrm{p}<.001\right)$. The two gender related topics ballet $(38.5 \%)$ and fashion $(30.8 \%)$ received the highest degree of preference mostly from female students. In addition, the students, irrespective their gender, showed interest in reading the text with 'neutral' topic (nutrition). However, a strong tension was revealed among male students to prefer reading two 'masculine' related topics: football (46.2\%) and electronics (30.8\%) (table 6).

\subsubsection{Verbal Data}

Students' verbal data, after being coded qualitatively, resulted into twenty three categories, which were grouped into three basic themes: (1) cognitive strategies, (2) metacognitive strategies, (3) text selection (table 7).

\section{Cognitive strategies}

The participants employed a significant number of cognitive strategies to facilitate reading and to make the text more comprehensible, like 'underlining', 'skimming', 'scanning', 'using imagery', 'finding key-words, 'placing words in the context', 'writing down unknown words', 'skipping the difficult parts', and 'consulting a dictionary' (table 8). Crosstabulation revealed statistically significant differences between male and female students in the following cognitive strategies.

1) 'Activating background knowledge' was used by the majority of the students in order to facilitate reading. However, the comparison between the two groups indicated statistically significant gender differences $\left(x^{2}=5.098\right.$. 
$\mathrm{df}=2, \mathrm{p}<.005)$, since the vast majority of the female students employed the specific strategy more frequently and efficiently (92.3\%) than the male students (61.5\%).

2) A considerable number of the students made use of the title and the pictures before starting reading the text in order to make it comprehensible. As regards 'imagery', statistically significant differences were found between female and male students $\left(\mathrm{x}^{2}=6.992\right.$. $\left.\mathrm{df}=2, \mathrm{p}<.005\right)$. Only $7.7 \%$ of the boys used the pictures in order to facilitate comprehension in contrast to girls, who got involved in using imagery to facilitate reading comprehension (53.8\%).

3) 'Guessing from the context' was employed with a high degree of flexibility and frequency by the majority of the students, irrespectively their gender (76.9\% of the male and $61.5 \%$ of the female students).

4) 'Underlining' either key words/phrases or unknown words $\left(\mathrm{x}^{2}=6.671, \mathrm{df}=2, \mathrm{p}<.005\right)$ was employed efficiently mostly by girls (61.6\%). However, the boys showed little preference for 'underlining' (15.4\%). Although a smaller number of students relied on 'decoding the words' for comprehension purposes, significant differences were found between the two subgroups $\left(\mathrm{x}^{2}=5.221 . \mathrm{df}=2, \mathrm{p}<.005\right)$; it was a more favourite strategy for the girls, since it was used by the girls either efficiently (23.1\%) or in a partial effective way (23.1\%) compared to the boys (15.4\%) (table 8).

5) Both subgroups (male and female students) showed preference for skimming the text for the gist. More precisely, the majority of the girls were engaged in this process either efficiently (53.8\%) or in a partial effective way (38.5\%); also, a considerable number of the boys (53.8\%) got involved in 'skimming' the text. Significant differences resulted from gender in relation to the following cognitive strategies, which proved to be the least favourite ones: (1) 'summarizing' ( $\left.\mathrm{x}^{2}=5.727 . \mathrm{df}=1, \mathrm{p}<.005\right)$ was used efficiently by $30.8 \%$ of the girls, but none of the boys was found to use it; (2) 'note taking' was used efficiently by $38.5 \%$ of the girls, meanwhile $100 \%$ of the boys did not got involved in it $\left(\mathrm{x}^{2}=5.983 . \mathrm{df}=1, \mathrm{p}<.005\right)$ (table 8).

\section{Metacognitive strategies}

From a total of five metacognitive strategies reported in the study, 'rereading' was the most favourite strategy among male $(100 \%)$ and female students $(92.3 \%)$. No significant relationship was found between 'rereading for clarifying certain points' and gender. Moreover, no significant differences were found between the two groups in relation to 'selective attention', since both boys and girls seemed to be less willing to be engaged in this strategy (table 9).

However, significant relations were revealed between 'reading comprehension control' and the two subgroups $\left(x^{2}=6.196 \mathrm{df}=2, \mathrm{p}<.005\right)$; the female students got engaged in this strategy more efficiently $(69.2 \%)$ than the male ones, who did not manage to use it in an effective way (38.5\%). The female students had also significantly higher efficiency of awareness in 'identifying errors' and 'self correcting' than the male ones ( $\left.x^{2}=5.295 \mathrm{df}=2, \mathrm{p}<.005\right)$.

It is worth mentioning that a considerable number of students showed a positive attitude towards evaluating their own reading, and both male and female students placed emphasis on improving the following subskills: (1) reading sentence by sentence, (2) prosodic reading and (3) rapid reading.

Moreover, the independent sample t-test indicated that there were statistically significant differences between the two subgroups (male and female students) in using both cognitive and metacognitive strategies $(\mathrm{p}<0.05)$ (table 10).

\section{Discussion}

The present study replicates the findings of previous studies (Higginbotham, 1999; Brozo, 2002; Kim et al, 2002; Merisuo-Storm, 2006; Clark et al, 2008) by supporting the assumption that there is a relationship between gender and the reading attitudes, the types of texts students prefer to read, the amount of time allocated for leisure reading, as well as the flexibility in strategy use. Furthermore, the female students were recorded to make extensive use of a wider range of strategy repertoire and to show more strategic knowledge and flexibility in using both cognitive and metacognitive strategies. This is in accordance with the findings of much of the research published internationally ( Green \& Oxford, 1995; Chandler et al, 1998; Wharton, 2000; Griva \& Alevriadou, 2009; Griva et al, 2009). It was also revealed that mothers' occupational and educational background proved to be significant, since it influenced and defined male and particularly female students' reading attitudes and text choice. It is widely accepted that stereotypical gender behaviour can be reinforced by daily activities, media, as well as school activities.

School plays a central part in citizenship education, since it is a social and cultural context, where students develop their literacy skills and cultural identity and a personal sense of citizenship. Primary school should offer experiences and opportunities to develop students reading skills and strategies, as well as to build successfully on their experiences with literacy. Every school should promote and increase parental involvement and participation in promoting the social and academic growth of the children by strengthening involvement in children's school and out of school reading. Developing collaborations between families and schools to promote reading success has a long-standing basis in research and is the focus of numerous educational programs (Hill \& Taylor, 2004). In the 
school context, both male and female teachers need to offer interesting reading material for both male and female students. A variety of text types and reading activities can influence students' reading attitudes and enhance their motivation to read at school (Perry, Nordby \& VandeKamp, 2003). Reading material/activities can promote a more positive attitude towards reading, when adjusted to students' home and cultural experiences as well as to gender preferences.

In addition, students (especially the male ones) need to be explicitly taught effective ways and strategies to read texts in order to increase their intrinsic motivation (Guthrie et al., 1996; Walker, 2003). Thus, schools should follow a process-oriented approach aiming to: (1) promote reading awareness, accounting for students' linguistic and cognitive development and sociocultural background and (2) encourage their growth of metacognitive skills by training them into a variety of strategies (see Norris \& Ortega, 2000; Hartman, 2001).

The development of male and female students' literacy skills must be viewed as a key to the development of primary school students' citizenship in the classroom. Teachers should decide on the ways and reasons of 'creating' citizens of a literary society and educate students for global citizenship (Tanner, 2007). Since reading could be considered as a critical-social practice in an education context that would prevent inequities between genders, the opportunities for developing students' reading skills should contribute to the process of educating them for being active and responsible citizens. This could be achieved through students' participation in a creative literacy context, which entails the idea of male and female students as cosmopolitan citizens (Osler, 2011).

\section{Conclusion}

The findings of the present study reflect trends in primary school student behavior and preferences, as well as their level of engagement with reading that are influenced by gender, societal and familial factors and educational practices at school (Miller, 2003; Willis, 2002).

The results may enable teachers to have an understanding of students' reading attitudes and preferences in order to adopt appropriate teaching practices, such as a) rich print environment with many resources, b) whole school approaches to developing reading skills, c) real-world activities (Friend \& Kelly, 2005). Also, a large variety of texts available for reading could increase both male and female students' level of reading engagement into academic reading. Every effort should be made to enhance students' reading skills and their engagement with a wide range of reading texts, so as to develop students who cope with academically and socially and create citizens of a literary community that does not encourage biases and stereotypes.

Since 'reading and gender' in primary education remains an area open for research and discussion, several directions for future research could emerge considering sociocultural factors in a more rigorous way. Further research is needed to understand the associations between parental characteristics and reading to young children as well as teachers' attitudes and behaviour. This could contribute to the development of improved literacy interventions for young children and their families (Yarosz \& Barnett, 2001).

\section{References}

Abilock, D. (2002). How Gender Differences and Effect on Practice and Programs. Emergency Librarian, 24 (5), 17-18.

Adams, M. J. (1990). Beginning to read: Thinking and learning about print. Urbana, Illinois: Center for the Study of Reading.

Anderson, R. C. (1994). Role of readers schema in comprehension, learning, and memory, in R. Rudell. M. Rudell \& H. Singer (ed.), Theoretical Models and Processes of Reading, Newark, Delaware: IRA, pp. 448-468.

Anderson, R. C., \& Pearson, P. D. (1984). A schema-theoretic view of basic processes in reading comprehension, in P. D. Pearson (ed.), Handbook of Reading Research, New York: Longman, pp. 255-291.

Bauer, T. (2002). From "Citizens first" to "Citizen (ship) Education in Europe - Education in a European context, in. Ross, A. (ed.), Future Citizens in Europe, Proceedings of the fourth Conference of the Childrens Identity and Citizenship in Europe Thematic Network, London: CiCe, pp. 307-315.

Brozo, W. G. (2002). To be a boy, to be a reader: Engaging teen and preteen boys in active literacy. Newark, DE: International Reading Association.

Bügel, K., \& Buunk, B. P. (1996). Sex differences in foreign language text comprehension: The role of interests and prior knowledge. The Modern Language Journal, 80 (1), 15-31.

Chandler, J., Lizotte R., \& Rowe, M. (1998). Adapting teaching methods to learners preferences, strategies, and needs. College ESL, 8, 48-69. 
Chavez, M. (2001). Gender in the language classroom. Boston: Heinle \& Heinle.

Clark, C., Osborne, S., \& Akerman, R. (2008). Young peoples self-perceptions as readers: An investigation including family, peer and school influences. London: National Literacy Trust.

Comber, B. (2004). Three little boys and their literacy trajectories. Australian Journal of Language and Literacy, 27 (2), 114-127.

Davis, J. N., \& Bistodeau, L. (1993). How do L1 and L2 reading differ? Evidence from think aloud protocols. The Modern Language Journal, 77 (4), 459-471.

Devine, J. (1993). The role of metacognition in second language reading and writing, in J. Carson \& I. Leki (ed.). Reading in the composition classroom: Second language perspectives. Boston MA: Heinle \& Heinle, pp. 105-121.

Friend, L., \& Kelly, D. (2005). Rich tasks and the blending of old and new basics. Practically Primary, 10 (3), 20-22.

Galston, W. A. (2001). Political knowledge, political engagement, and civic education. Annual Review of Political Science. 4, 217-34. http://dx.doi.org/10.1146/annurev.polisci.4.1.217

Garner, R. (1987). Metacognition and executive control. Theoretical models and processes of reading, Newark, DE: International Reading Association.

Gibbons, J. L., Lynn, M., \& Stiles, D. A. (1997). Cross-National Gender Differences in Adolescents Preferences for Free-Time Activities. Cross-Cultural Research, 31 (1), 55-69. http://dx.doi.org/10.1177/106939719703100104

Green, J. M., \& Oxford, R. (1995). A closer look at learning strategies, L2 proficiency, and gender. TESOL Quarterly, 29 (2), 261-297. http://dx.doi.org/10.2307/3587625

Green, P. (2002). Teachers' intervention in children's reading. Journal of Childhood Education, 46 (3), 147-149.

Griva, E., Alevriadou, A., \& Geladari, A. (2009). A qualitative study of poor and good bilingual readers strategy use in EFL reading. The International Journal of Learning, 16 (1), 51-72.

Griva, E., Alevriadou, A., Xanthidou, P., \& Tsakiridou, E. (2009). Minority Language Students: a comparative account of good and poor writers strategies in Greek and in a foreign language, in the proceedings of International Conference IAIE. Intercultural education: Paideia, Polity, Demoi, Athens, 24-26 June.

Guthrie, J. T., \& Wigfield, A. (2000). Engagement and motivation in reading, in M. L. Kamil, P. B. Mosenthal, P. D. Pearson, \& R. Barr (ed.). Handbook of reading research, New Jersey: Lawrence Erlbaum Associates, pp. 403-422.

Guthrie, J. T., McGough, K., Bennett, L., \& Rice, M. E. (1996). Concept-oriented reading instruction: An integrated curriculum to develop motivations and strategies for reading, in L. Baker, P. Afflerbach, \& D. Reinking (ed.). Developing engaged readers in school and home communities, Mahway, New Jersey: Lawrence Erlbaum Associates, pp. 165-190.

Hartman, H. J. (2001). Metacognition in learning and instruction: theory, research and practice. Norwell, MA: Klewer Pub.

Higginbotham, S. (1999). Reading interests of middle school students and reading preferences by gender of middle school students in a Southeastern State. Masters Thesis, Mercer University, ED 429279.

Hill, N. E., \& Taylor, L. C. (2004). Parental school involvement and childrens academic achievement pragmatics and issues. Current Directions in Psychological Science, 13 (4), 161-164. http://dx.doi.org/10.1111/j.0963-7214.2004.00298.x

Kim, S., Dueker, G. L., Hasher, L., \& Goldsteinb, D. (2002). Childrens time of day preference: age, gender and ethnic differences. Personality and Individual Differences, 33, 1083-1090. http://dx.doi.org/10.1016/S0191-8869(01)00214-8

Koutselini, M., \& Agathangelou, S. (2008). The informal curriculum on gender identity, in Ross, A. \& Cunningham, P. (ed.). Reflecting on identities: research, practice and innovation, London: CiCe, pp. 531-540.

Kraaykamp, G. (2001). Parents, personality and media preferences communications. The European Journal of Communication Research, 26, 15-38.

Lee, H. W. (1994). Investigating the factors affecting the use of foreign language learning strategies and comparing the strategy use of EFL and ESL students. English Teaching. 48, 51-99.

McCarthy, S. J., \& Moje, E. B. (2002). Identity matters. Reading Research Quarterly, 37 (2), 228-238. http://dx.doi.org/10.1598/RRQ.37.2.6 
Merisuo-Storm, T. (2006). Girls and boys like to read and write different texts. Scandinavian Journal of Educational Research. 50, 111-125. http://dx.doi.org/10.1080/00313830600576039

Miller, S. D. (2003). How high and low challenge tasks affect motivation and learning: Implications for struggling learners. Reading and Writing Quarterly. 19 (1), 39-58. http://dx.doi.org/10.1080/10573560308209

Morrison, L. (1996). Talking about words: A study of French as a second language learners lexical inferencing procedures. The Canadian Modern Language Review, 53 (1), 41-66.

Myoungsoon, K., \& Heekyoung, K. (2002). The differences in attitudes toward emergent literacy of children among teachers, mothers, and fathers in kindergartens and daycare centers in Korea. Reading Improvement, 39 (3), 124-148.

Norris, J. M., \& Ortega, L. (2000). Effectiveness of L2 instruction: A research synthesis and quantitative meta-analysis. Language Learning, 50 (3), 417-528. http://dx.doi.org/10.1111/0023-8333.00136

O’ Malley, J. M., \& Chamot, A. U. (1990). Learning strategies in second language acquisition. Cambridge: Cambridge University Press.

Osler, A. (2011). Education policy, social cohesion and citizenship, in P. Ratcliffe and I. Newman (ed.). Promoting Social Cohesion: implications for policy and frameworks for evaluation. Bristol: Polity Press.

Oxford, R. L. (1990). Language Learning strategies. USA: Heinle and Heinle Publishers.

Oxford, R. L., \& Nyikos, M. (1989). Variables affecting choice of language learning strategies by university students. The Modern Language Journal. 73, 291-300.

Perry, N. E., Nordby, C. J., \& VandeKamp, K. O. (2003). Promoting self-regulated reading and writing at home and school. The Elementary School Journal, 103 (4), 317-338. http://dx.doi.org/10.1086/499729

Rowe, K. J. (1991). The influence of reading activity at home on students' attitudes towards reading, classroom attentiveness and reading achievement: An application of structural equation modeling. British Journal of Educational Psychology, 61 (1), 19-35. http://dx.doi.org/10.1111/j.2044-8279.1991.tb00958.x

Santora, E. D. (2006). Narrating democratic education. Social Studies Research and Practice. 1 (1), 17-29.

Shelly, H. (1990). Reading interests of middle school students and reading preferences by gender of students in a Southeast State. Master thesis, University of Mercer, ERIC, ED42279.

Simpson, A. (1998). Fictions and facts, investigations of the reading practices of girls and boys. British Educational Research, 28 (4), 106-108.

Swalander L., \& Taube K. (2007). Influences of family based prerequisites, reading attitude, and self-regulation on reading ability. Contemporary Educational Psychology, 32, 206-230. http://dx.doi.org/10.1016/j.cedpsych.2006.01.002

Tanner, J. (2007). Global citizenship, in D. Hicks \& C. Holden (ed.). Teaching the global dimension: Key principles and effective practice, London: Routledge, pp. 150-160.

Thomson, P. T. (2002). Schooling the rust belt kids: Making the difference in changing times. Crows Nest, NSW: Allen \& Unwin.

Turner, J., \& Paris, S. G. (1995). How literacy tasks influence children's motivation for literacy. The Reading Teacher. 48 (8), 662.

Van Peer, W. (1991). Literary socialization in the family: a state of the art. Poetics. 20, 539-558. http://dx.doi.org/10.1016/0304-422X(91)90024-J

Walker, B. J. (2003). The cultivation o student self-efficacy in reading and writing. Reading and Writing Quarterly. 19 (1), 173-187. http://dx.doi.org/10.1080/10573560308217

Wharton, G. (2000). Language learning strategy use of bilingual foreign language learners in Singapore. Language Learning, 50 (2), 203-244. http://dx.doi.org/10.1111/0023-8333.00117

Willis, A. I. (2002). Dissin' and disremembering: Motivation and culturally and linguistically diverse students' literacy learning. Reading and Writing Quarterly, 18 (4), 293-319. http://dx.doi.org/10.1080/07487630290061854

Witt, S. (1997). The influence of peers on childrens socialization to gender roles. Early Child Development and Care, 162, 1-7. http://dx.doi.org/10.1080/0300443001620101

Yarosz, D. J., \& Barnett, W. S. (2001). Who reads to young children? Identifying predictors of family reading activities. Reading Psychology, 22, 67-81. http://dx.doi.org/10.1080/02702710151130235 
Table 1. Parents' education background

\begin{tabular}{|l|l|l|}
\hline Parent education background & Father & Mother \\
\hline Primary education & $31(7.7 \%)$ & $15(3.7 \%)$ \\
\hline Secondary education & $155(38.3 \%)$ & $136(33.6 \%)$ \\
\hline Tertiary education & $219(54.1 \%)$ & $254(62.7 \%)$ \\
\hline
\end{tabular}

Table 2. Parents' occupation background

\begin{tabular}{|l|l|l|}
\hline Occupation & Father & Mother \\
\hline $\begin{array}{l}\text { Low autonomy } \\
\text { profession }\end{array}$ & $211(52.1 \%)$ & $274(67.7 \%)$ \\
\hline $\begin{array}{l}\text { High autonomy } \\
\text { profession }\end{array}$ & $194(47.9 \%)$ & $131(32.3 \%)$ \\
\hline
\end{tabular}

Table 3. Out of school reading preferences

\begin{tabular}{|l|l|l|l|l|l|l|l|l|}
\hline \multirow{2}{*}{ Questions } & \multicolumn{2}{l}{ very much (n) } & \multicolumn{2}{c|}{ much (n) } & \multicolumn{2}{c|}{ fairly (n) } & \multicolumn{2}{l|}{ very little (n) } \\
\cline { 2 - 11 } & boys & girls & boys & girls & boys & girls & boys & girls \\
\hline I like leisure reading & 17 & 78 & 83 & 62 & 75 & 59 & 31 & - \\
\hline I like buying books & 12 & 32 & 30 & 46 & 126 & 112 & 38 & 9 \\
\hline I like going to the library & 6 & 40 & 55 & 25 & 90 & 94 & 55 & 40 \\
\hline I prefer watching TV to reading books & 105 & 91 & 58 & 27 & 34 & 60 & 9 & 21 \\
\hline I prefer computer games to reading books & 104 & 80 & 61 & 33 & 27 & 70 & 14 & 16 \\
\hline
\end{tabular}

Table 4. Preferred types of reading texts

\begin{tabular}{|l|l|l|l|l|l|l|l|l|}
\hline \multirow{2}{*}{ Questions } & \multicolumn{2}{|c|}{ very much (n) } & \multicolumn{2}{c|}{ much (n) } & \multicolumn{2}{c|}{ fairly (n) } & \multicolumn{2}{c|}{ very little (n) } \\
\cline { 2 - 10 } & boys & girls & boys & girls & boys & girls & boys & girls \\
\hline Adventures & 125 & 123 & 44 & 42 & 26 & 18 & 11 & 16 \\
\hline Fairytales & 33 & 56 & 35 & 55 & 54 & 55 & 84 & 33 \\
\hline Comics & 119 & 77 & 45 & 47 & 34 & 47 & 8 & 28 \\
\hline Funny stories & 160 & 145 & 21 & 23 & 19 & 15 & 6 & 6 \\
\hline Sport magazines & 106 & 16 & 35 & 32 & 27 & 32 & 38 & 119 \\
\hline Magazines (TV, fashion etc) & 38 & 66 & 11 & 45 & 87 & 37 & 70 & 51 \\
\hline Poems & 9 & 42 & 34 & 30 & 41 & 61 & 122 & 66 \\
\hline
\end{tabular}


Table 5. Students' difficulties while reading school books

\begin{tabular}{|l|l|l|l|l|l|l|l|l|}
\hline \multirow{2}{*}{ Questions } & \multicolumn{2}{|c|}{ very much(n) } & \multicolumn{2}{c|}{ much (n) } & \multicolumn{2}{c|}{ fairly (n) } & \multicolumn{2}{c|}{ Very littl(n) } \\
\cline { 2 - 10 } & Boys & Girls & Boys & girls & boys & girls & Boys & Girls \\
\hline Extensive reading & 7 & 19 & 39 & 35 & 81 & 66 & 78 & 76 \\
\hline Skimming the text for gist & 18 & 29 & 24 & 30 & 72 & 60 & 92 & 77 \\
\hline Learning a text by heart (unknownwords) & 23 & 26 & 41 & 47 & 69 & 72 & 73 & 51 \\
\hline Complex sentences/paragraphs & 19 & 19 & 18 & 30 & 35 & 51 & 134 & 96 \\
\hline
\end{tabular}

Table 6. Students' preferred topics of reading texts

\begin{tabular}{|l|l|l|l|l|l|l|}
\hline & Text 1 & Text 2 & Text 3 & Text 4 & Text 5 & Total \\
\hline & nutrition & football & electronics & ballet & fashion & \\
\hline Male & $23.1 \%$ & $46.2 \%$ & $30.8 \%$ & - & - & $100.0 \%$ \\
\hline Female & $30.8 \%$ & - & - & $38.5 \%$ & $30.8 \%$ & $100.0 \%$ \\
\hline Total & $26.9 \%$ & $23.1 \%$ & $15.4 \%$ & $19.2 \%$ & $15.4 \%$ & $100.0 \%$ \\
\hline
\end{tabular}

Table 7. Categories and subcategories of cognitive and metacognitive strategies

\begin{tabular}{|c|c|}
\hline Categories & Subcategories \\
\hline Student profile & \\
\hline 1. TEXT SELECTION & $\begin{array}{ll}\text { - } & \text { Preference } \\
\text { - } & \text { Rejection }\end{array}$ \\
\hline $\begin{array}{l}\text { 2. COGNITIVE } \\
\text { STRATEGIES }\end{array}$ & $\begin{array}{ll}\text { - } & \text { Skimming for gist } \\
\text { - } & \text { Scanning } \\
\text { - } & \text { Using titles } \\
\text { - } & \text { Guessing from the context } \\
\text { - } & \text { Activating background knowledge } \\
\text { - } & \text { Using synonyms } \\
\text { - } & \text { Using a dictionary } \\
\text { - } & \text { Summarizing } \\
\text { - } & \text { Decoding words } \\
\text { - } & \text { Repeating a word/phrase } \\
\text { - } & \text { Underlining key words/phrases } \\
\text { - } & \text { Underlining unknown words } \\
\text { - } & \text { Skipping a word/phrase } \\
\text { - } & \text { Note taking }\end{array}$ \\
\hline $\begin{array}{l}\text { 3. METACOGNITIVE } \\
\text { STRATEGIES }\end{array}$ & $\begin{array}{ll}\text { - } & \text { Selective attention } \\
\text { - } & \text { Prediction and verification } \\
\text { - } & \text { Control of reading comprehension } \\
\text { - } & \text { Rereading for overcoming difficulties } \\
\text { - } & \text { Error identification and self correction }\end{array}$ \\
\hline
\end{tabular}


Table 8. Cognitive strategies employed by male and female students

\begin{tabular}{|l|l|l|l|l|l|l|}
\hline & \multicolumn{3}{|c|}{ Male students } & \multicolumn{3}{c|}{ Female students } \\
\hline Cognitive strategies & $\mathbf{0}$ & $\mathbf{1}$ & $\mathbf{2}$ & $\mathbf{0}$ & $\mathbf{1}$ & $\mathbf{2}$ \\
\hline Skimming for gist & $15.4 \%$ & $30.8 \%$ & $53.8 \%$ & $7.7 \%$ & $38.5 \%$ & $53.8 \%$ \\
\hline Scanning & - & $53.8 \%$ & $46.2 \%$ & $7.7 \%$ & $30.8 \%$ & $61.5 \%$ \\
\hline Using titles & - & $7.7 \%$ & $92.3 \%$ & - & $15.4 \%$ & $84.6 \%$ \\
\hline Imagery & $30.8 \%$ & $61.5 \%$ & $7.7 \%$ & $7.7 \%$ & $38.5 \%$ & $53.8 \%$ \\
\hline Guessing from the context & - & $23.1 \%$ & $76.9 \%$ & - & $38.5 \%$ & $61.5 \%$ \\
\hline $\begin{array}{l}\text { Activating background } \\
\text { knowledge }\end{array}$ & $15.4 \%$ & $23.1 \%$ & $61.5 \%$ & - & $7.7 \%$ & $92.3 \%$ \\
\hline Using a dictionary & $92.3 \%$ & $7.7 \%$ & - & $76.9 \%$ & $23.1 \%$ & - \\
\hline Summarizing & $100 \%$ & - & - & $69.2 \%$ & $30.8 \%$ & - \\
\hline Decoding words & $84.6 \%$ & - & $15.4 \%$ & $53.8 \%$ & $23.1 \%$ & $23.1 \%$ \\
\hline $\begin{array}{l}\text { Underlining key } \\
\text { words/phrases }\end{array}$ & $84.6 \%$ & - & $15.4 \%$ & $38.5 \%$ & $30.8 \%$ & $30.8 \%$ \\
\hline Skipping a word/phrase & $46.2 \%$ & $53.8 \%$ & - & $69.2 \%$ & $30.8 \%$ & - \\
\hline Note taking & $100 \%$ & - & - & $61.5 \%$ & $38.5 \%$ & \\
\hline & & & & & & \\
\hline
\end{tabular}

Table 9. Metacognitive strategies employed by male and female students

\begin{tabular}{|l|l|l|l|l|l|l|}
\hline & \multicolumn{3}{|c|}{ Male students } & \multicolumn{3}{c|}{ Female students } \\
\hline Metacognitive strategies & $\mathbf{0}$ & $\mathbf{1}$ & $\mathbf{2}$ & $\mathbf{0}$ & $\mathbf{1}$ & $\mathbf{2}$ \\
\hline Selective attention & $76.9 \%$ & $23.1 \%$ & - & $84.6 \%$ & $15.4 \%$ & - \\
\hline Control of reading comprehension & $38.5 \%$ & $15.4 \%$ & $46.2 \%$ & $7.7 \%$ & $23.1 \%$ & $69.2 \%$ \\
\hline $\begin{array}{l}\text { Rereading for overcoming } \\
\text { identified difficulties }\end{array}$ & - & - & $100 \%$ & & $7.7 \%$ & $92.3 \%$ \\
\hline Prediction and verification & $15.4 \%$ & $53.8 \%$ & $30.8 \%$ & & $69.2 \%$ & $30.8 \%$ \\
\hline $\begin{array}{l}\text { Error Identification and Self } \\
\text { correction }\end{array}$ & $15.4 \%$ & $84.6 \%$ & - & $15.4 \%$ & $46.2 \%$ & $38.5 \%$ \\
\hline
\end{tabular}

Table 10. Mean scores in cognitive and metacognitive strategy use

\begin{tabular}{|l|c|c|}
\hline \multicolumn{1}{|c|}{ Strategies } & Male students & Female students \\
\hline Cognitive & 6.77 (SD 1.01) & 8.26 (SD 1.96) \\
\hline Metacognitive & 3.84 (SD 0.69) & 4.46 (SD 0.66) \\
\hline
\end{tabular}




\title{
Business Studies Academic Performance Differences of Secondary School Juniors in Akwa Ibom State of Nigeria
}

\author{
Udoukpong, Bassey E. \\ Department of Educational Foundations, Guidance and Counselling \\ University of Uyo, Uyo, Nigeria \\ Emah, Ime E. \\ Department of Curriculum Studies, Educational Management and Planning \\ University of Uyo, Uyo, Nigeria \\ Umoren, Shirley E. \\ Government Technical College, Uyo, Nigeria
}

Received: December 9, 2011

Accepted: December 12, 2011 Published: April 1, 2012

doi:10.5539/ies.v5n2p35

URL: http://dx.doi.org/10.5539/ies.v5n2p35

\begin{abstract}
The research examined the differences in the academic performance in Business Studies of a sampled secondary school junior students in Akwa Ibom State of Nigeria. A sample of 290 (138 male and 152 female) Junior Secondary Three $\left(9^{\text {th }}\right.$ grade) students was surveyed. The students' variables' being examined vis-à-vis academic performance in Business Studies were: 1) gender and 2) self-concept. Students' academic performance in Business Studies differed significantly on the basis of gender and self-concept. Implications for students' personal variables considerations in the teaching-learning of Business Studies are suggested.
\end{abstract}

Keywords: Business studies, Gender, Self-concept, Academic performance

\section{Introduction}

In most countries as in Nigeria, curriculum is developed to meet the national goals and objectives in the various fields and stages of manpower needs and development. It is therefore pertinent to observe that the introduction of the 6-3-3-4 system currently referred to as the 9-3-4 (9-Year Basic Education: Primary 1 to Junior Secondary 3; 3-Year Senior Secondary Education and 4-Year Tertiary Education) educational system in Nigeria had the goals and the operation of the system in line with the country's national education goals as highlighted in the National Policy on Education. The Nigerian national educational goals which are derived from the country's philosophy and goals include, "the acquisition of appropriate skills and the development of mental, physical and social abilities and competencies as equipment for the individual to live in and contribute to the development of the society" (Federal Republic of Nigeria (FRN), 2004:8).

In order to realize fully the potentials of the contributions of education to the achievement of the national educational goals, emphasis is placed on the broad goals of secondary education which aim at preparing individuals for "useful living within the society and for higher education" (FRN, 2004:18). More specifically, in the junior secondary the curriculum provides for both the academic and pre-vocational subjects. The focus of the secondary education at the junior level targets the realization of the following goals, "to offer diversified curriculum to cater for the differences in talents, opportunities and future roles; to provide trained manpower in the applied sciences, technology and commerce at sub-professional grades, and to provide technical knowledge and vocational skills necessary for agricultural, industrial, commercial and economic development” (FRN, 2004:17-19). These goal statements had guided the efforts toward the developing of new curricula for the junior secondary education in the pre-vocational electives which include, "Agriculture, Business Studies, Home Economics, Computer Education, Fine Arts and Music” (FRN, 2004:20).

Business Studies is taught as one of the basic subjects that will enable students acquire further skills which are common and fundamental to all personal and occupational activities (Inyang, 1998). Business activity affects the 